\title{
Innovation Management in Wine Business - Need to Address Front-End, Back-End, or Both?
}

\author{
Marc Dressler ${ }^{1}$ (1) \\ ${ }^{1}$ Business Administration and Entrepreneurship, University of Ludwigshafen / Weincampus Neustadt \\ Keywords: wine industry, business ecosystem, strategy, strategic innovation, bandwaggoning, resource dependency \\ https://doi.org/10.26813/001c.31770
}

Wine Business Journal

Vol. 5, Issue 1, 2022

In order to provide needed orientation of innovation management in the SME wine industry, a multi-case study was realized. The innovation activities of four German wineries for their entire value-creation coverage were analysed. The focus of the study was on an apparent challenge whether wineries should emphasise viticultural (back-end) or marketing and sales (front-end) innovations. The results of the four cases analysed suggest that innovation matters, strategic positioning influences each wineries' innovation portfolio, winery size and organization impact the innovation portfolio, resource dependency can be reduced through cooperative action at the industry level, and smaller producers must leverage their entrepreneurial orientation. All integrated wine producers need to address front- and back-end innovation, but with flexibility for innovation accentuation and individual innovation portfolios. Wineries also need to recognize the synergetic value of two different challenges: (1) convincing products require optimal planting and farming whereas (2) the product assortment and its treatment should consider customer profiles. Hence, front- and back-end innovations need to be synchronized and considered in parallel, without ignoring each winery's strategic accents and therefore individualization of the innovation portfolio. A synergetic innovation approach, exploiting technology and data mining, can foster the development of competencies and best practices when using existing wine industry resources and capabilities. Knowledge exchange at the industry-level helps producers reach consensus on innovation activities, goals, and strategies, and to improve the business ecosystem by identifying elements that are obsolete or ripe for change.

\section{INTRODUCTION}

Innovation is about introducing something new. Novelty can be in different forms, e.g. an idea, a product, a process or a method. Innovation thereby results not only from research, new technology, and the natural sciences but also from the economics and management sciences in that they are social phenomena that emerge from attempts to meet the needs of individuals as well as society as a whole (Lucke, 1995; Schumpeter, 1939). Innovation is considered a panacea to compete in today's competitive markets and is therefore defined to be key for companies to develop, grow, position, and sustainably secure profitability in competitive business environments, especially where there are changing customer needs (Crossan \& Apaydin, 2010; D’Aveni, 1994; Denton, 1999; Hauschildt, 2004; Jenssen \& Jorgensen, 2004; Johannessen et al., 1999; Wang \& Ahmed, 2004).

Firms, in their quest for competitive advantage, innovate by developing new products, as well as new product-related services and manufacturing technologies, and by implementing innovative organisational concepts (Kirner et al., 2009; Le Roy et al., 2018). Innovation serves to exploit value creation potential (Adner \& Kapoor, 2010). It is in the interest of economies and societies to create new solutions and tap new needs by innovation (OECD, 2004; Van de Ven, 1986). Industries hence increasingly evolve from being factor-oriented to become innovation-driven (Prajogo \& Ahmed, 2006; Woodward, 2005). Digitalization serves hereby as an illustration, that innovation is a goal, a lever, a driver for change, but also a possible solution (Agostini \& Filippini, 2019). The pressure to innovate requires a holistic perspective of firm's knowledge capabilities with public policies and industrial structures (Camisón \& Monfort-Mir, 2012; Pang et al., 2019). In practice, innovation is a complex phenomenon embedded in multi-level innovation systems (Lundvall, 1992). Especially agricultural industries rely on innovation to cope with increasingly volatile and often destructive natural phenomena. In regards to the wine industry, players are deemed to not only innovate to manage potential external risks but also to be able to compete in international consumer markets and against a wide variety of substitute products (Aylward, 2006; Aylward et al., 2006; Granata et al., 2019; Rama \& von Tunzelmann, 2008). Addressing innovation from an upstream perspective (activities close to the exploitation of natural resources and therefore viticulture)-hereafter termed back-end innovation, and a downstream perspective (securing market access and customer acquisition and loyalty)-labeled as front-end in- 
novation stretches the innovation portfolio of wine estates (Singer \& Donoso, 2008).

Examining the innovation portfolio of wineries allows us to assess actual innovation activities. It provides information on innovation diffusion and in case a firm launches several innovations, the innovation intensity of the firm's portfolio can be explored. The German wine industry is characterized by fragmentation and predominantly small companies (BMEL, 2016, 2021; BMELV, 2012; DWI, 2020; Loose \& Pabst, 2018). Acknowledging that small enterprises suffer a comparative disadvantage in resource access compared to large companies (McGee, 2000) and an apparent stretch to address up- and downstream innovation for vertically integrated wine producers motivated an explorative multi-case study to assess their innovation strategies.

Four German wineries compose the basis for analysis. Case data was gathered in a time span from November 2019 until March 2021. Multi-case research methodology is appropriate when exploring entrepreneurial aspects, such as innovation strategy of SMEs, “... since the researcher does not impose a priori categories or hypotheses, but rather attempts to understand phenomena based on field research" (Dana \& Dana, 2005). An iterative interviewing of the managers and owners of the four wineries and winery visits served to gather the status of innovation in the German wine industry from the perception of interviewees, a merged view of the four cases, and a comparison of the innovation portfolios of the participating wineries. The case analyses were combined with expert interviews. This approach allowed for the mapping of an innovation landscape when assessing each individual winery and asking the interview partners to state and rank current innovations in the industry.

This investigation consisted of iterative interviews and communication with the managers and industry experts. The drawn landscape of innovation does not claim to be exhaustive, neither objective, nor of long-term validity. It served as a means to compare the wineries and to shed light on the innovation portfolio of the participating wineries. For practitioners, the drawn map can serve to assess their degree of innovativeness. The multi-case approach allowed for the identification of innovative measures at each step of the value-chain, interact with the case owners on their respective innovation strategy, validate innovation aspects for each winery, and create a comparison across the case studies (Eisenhardt, 1989; Gilinsky et al., 2016; Marion et al., 2012; Yin, 2008). All four cases represent small to medium sized entities in the German wine industry, covering value-creation from wine production to sales.

Managerial demand to manage innovation is high, considering increasing complexity, financial burdens, shorter product life cycles, and digitalization in the wine industry. Especially small and medium sized enterprises with limited resources need to manage innovation wisely. Resource dependency might limit innovativeness and strategic innovation decision making. Innovation portfolio should be a strategic result and not one of imitating peers. The goal of this research is not only to understand innovation in the industry but also, more importantly, to apply a strategic and business ecosystem perspective to the German wine business for the purposes of adding knowledge to the less searched field of strategic innovations. Practitioners in the entrepreneurial wine industry are apparently pushed to be innovative (Dressler, 2013). Innovativeness in the wine industry is not about being innovative per se but rather it is about investing wisely and deciding in which activities of the firm to innovate or not. Indeed, all four wineries were active in all value-chain process steps and engage in frontend (close to the customer) and back end (viticulture-oriented) innovation.

By analysing the innovation portfolios of each winery, the multi-case approach allowed for capturing both innovation breadth and depth. The analyses intended to contribute to explore each firm's (a) innovation strategies and profiles of innovation, (b) status of innovation diffusion, and (c) to explore barriers and levers for innovation in the light of resource dependency. Exploring limitations in resource access or asymmetrical power situations determine strategic decisions such as innovation activities (Barney, 2001). The cases hereby allowed to explore innovation strategies from the back end (wine production) to the front end (customer end) of the value creation steps.

The innovation strategies of the analysed wineries speak for the need to cover both innovation perspectives but also to synchronize the two. The larger and cooperatively organized winery showed highest innovation activity levels, also for the back- and front-end innovation measures of all cases. The findings can be explained with their superior resource access and overcoming resource limitations. A result of this fruitful interaction with the winery owners over the course of this study was a jointly created innovation map that indicated that joint approaches, exchange, and cross-winery learnings are a lever for innovation diffusion and value creation in innovation ecosystems (Kenney et al., 2020).

\section{LITERATURE REVIEW}

Firm innovation is a vastly studied research topic which has led to a well-developed innovation research stream (Adner \& Kapoor, 2010; Calantone et al., 2002; Chesbrough, 2010; Crossan \& Apaydin, 2010; Danneels, 2002; Glynn, 1996; Hauschildt, 2004; Jenssen \& Jorgensen, 2004; Knight \& Cavusgil, 2004; Le Roy et al., 2018; Prajogo \& Ahmed, 2006; Salavou, 2004; Schneider \& Spieth, 2013; Wang \& Ahmed, 2004). Initially, innovation studies focused on larger organizations (Caputo et al., 2002; Gilinsky et al., 2008; Vermeulen et al., 2005), yet recent studies have increasingly focused on small- and medium-enterprises (SME) (Freel, 2005; Saunila, 2020). The literature provides empirically-based recommendations for innovation management of SME innovation processes (Scozzi et al., 2005), for the food and beverages industry (Rama \& von Tunzelmann, 2008), herein the wine industry (Gilinsky et al., 2008), and even focal areas in innovation management such as sustainability oriented innovation practices in the wine business (Lubell et al., 2011). Indeed, research on innovation in the context of SMEs and especially in the wine industry is on the rise (Crossan \& Apaydin, 2010; Orth et al., 2007)

In the agricultural sector, the innovation process has specificities compared to the innovation process in other 
productive sectors. The agricultural value chain consists of upstream activities of planting, growing, harvesting, and production, as well as downstream activities to create and cater to market demand (Singer \& Donoso, 2008). Within the agricultural industry, wine benefits from being a product of emotional utility, and therefore high value-creation potential in the downstream activities, evidenced by the range of wine prices (Ashton, 2011; Lecat et al., 2017; Rössel, 2012; Schnabel \& Storchmann, 2010; Storchmann, 2012). Societal changes, digitalization, increasing knowledge, and technological advances allow wineries to create new offerings and a formerly unknown variety of offerings. Innovation-driven downstream activities potentially create a challenge for upstream innovation and may limit the ability to meet market expectations in light of the complexity, dependency, or conflicting targets inherent in innovation processes (e.g. upstream-innovation for cost savings) (Carter, 1990; Roy \& Sivakumar, 2010). As a result, there is a potential innovation stretch when intending to be innovative in all value-creation aspects (i.e. front-end and backend innovations). In the wine industry, vertically integrated wineries need to address both perspectives also from an innovation management perspective. Indeed, innovation diffusion depends on both perspectives and their mutual interaction (Rogers, 1995). Gains from technological innovation are quickly passed on to consumers because in a fully commercialised economy demand and supply are engaged in a price race and, consequently, an income distribution race: a so-called "agricultural treadmill" (Cochrane, 1958). In effect, this means that the only way for agricultural producers to obtain higher prices and avoid business failure is to create emotional utility for consumers (Best, 2010; Khan \& Mohsin, 2017; Verbeke, 2005). Here, the industry can look to high-tech innovation when considering ways to secure income gains from innovation that remain in the wine industry and are not quickly passed on to wine consumers or to other industries.

Marketing can create strong position barriers, helping create and protect profits from entrepreneurial acts, but (upstream) technical capabilities may constrain thus hampering the effectiveness of an EO under imitability conditions (García-Villaverde et al., 2013). Business ecosystems, spanning the boundaries within and across industry players, serve as accelerators for industry-wide innovation (AlAali \& Teece, 2013). One promising approach to innovation in the wine business has been the application of regional development and destination governance concepts such as co-innovation competence (Doepfer, 2012) and joint innovation approaches (Fischer, 2011). These concepts are suitable for governing loose innovation networks in a geographically confined space, and both approaches are rooted in Porter's (2000) concept of clusters as geographically grouped firms, institutions, research facilities, suppliers, and service providers. There is a strong positive correlation between collaborative research on one hand and innovation performance on the other, but potential drawbacks of cooperation are knowledge disclosure, risks of disloyal partner behaviour, and the cost of coordination and monitoring within a network (Hottenrot and Lopes-Bento, 2016). This is why the influence of knowledge networks represents a complex phenomenon, where a multitude of factors influ- ence the wineries' ability to use the network as a development tool (Hojman, 2015). Only firms with resources and the capability to follow through on innovation were able to capitalise on knowledge-sharing opportunities (Taplin, 2012). “Technological leaders" foster the dissemination of innovation-related knowledge to other firms as a contribution to the development of the wine industry. Benchmarking and transparency on innovativeness serve as levers to foster innovation diffusion (Goldsmith, 2000; Schuhmacher et al., 2018; Vrontis et al., 2016; Wood \& Hoeffler, 2013).

The theory of resource dependency offers explanatory value to assess limitations in access to resources and capacity restrictions (Forsman, 2011; Terziovski, 2010) for small enterprises (Calantone \& Rubera, 2012; Carter, 1990; García-Villaverde et al., 2013; Roy \& Sivakumar, 2010; Singer \& Donoso, 2008; Teece, 2007). A parallel pursuit of product and process innovation seems to be a stretch in light of capacity restrictions of small firms (Harmsen et al., 2000). Indeed, whether firm size nurtures or hampers innovativeness is still a matter of debate (Freel, 2005; Harrison, 1994; Mazzarol \& Reboud, 2008; Stoeberl et al., 1998). In the German wine industry, even small players aim to strongly innovate, eventually ignoring a lack of innovation capacity (Dressler, 2016). Bandwaggoning explains innovation as a result of imitation (Abrahamson, 1991, 1996; Giuliani et al., 2017) but also brings into question the value-creation potential of such innovation strategy.

Innovativeness and the effects of innovation represent an ongoing challenge in practice with further need for research and insights (Giuliani et al., 2017; Granata et al., 2019; Le Roy et al., 2018; Lubell et al., 2011; Moore \& Benbasat, 1991). The proclaimed far reaching transformation in the wine industry from a product to a customer-centric business model (Dressler \& Paunović, 2019, 2020; SánchezHernández et al., 2010) requires a systemic innovation in order to increase innovation capacity (Jørgensen \& Ulhøi, 2010) and further exploration of innovation and innovators (F. A. Garcia et al., 2012; R. Garcia \& Calantone, 2002).

The global wine industry is mature and has a longstanding tradition, especially in the "old wine world" with historic production (e.g. Spain, France, Italy, Germany) but ongoing structural changes (Corsi et al., 2011; Gilinsky et al., 2014; Loose \& Pabst, 2018; Remaud \& Couderc, 2006; Storchmann, 2012). Global supply and competition, changes in consumer behaviour and preferences, and international markets with individually- and culturally-influenced consumption behavior characterize the global wine industry (Anderson \& Nelgen, 2009; Gilinsky et al., 2014; Müller \& Bürgelt, 2006; Santini et al., 2014; Schrader, 2008; Thomas et al., 2013). In the last 30 years, the number of German wine growers has massively declined by more than 50 percent, but the industry still shows a high degree of fragmentation (Anonymous, 2018; BMEL, 2016, 2019, 2021; BMELV, 2011; Datamonitor, 2010; Hoffman, 2013; Lambeck, 2013; Minnici \& Merlin, 2016; Oberhofer, 2011; Scheuermann, 2012; Statistisches Bundesamt, 2010). The industry is characterized by small and medium players with an average revenue of less than one million Euros annually (Dressler, 2018). Although small in size, the wineries are predominantly highly integrated - from growing to harvesting to producing to sales and marketing. 
Wineries hence need managerial competence for all value chain steps, and also to cope with the need for change and business model adaptation (BMEL, 2019). The integrated value chain coverage of the majority of the wineries results in the need for firms to develop competencies for multiple markets and this in turn impacts winery's innovation behaviour. Additionally, the wine business belongs in the agricultural sector, with its strong dependency on nature (Ashenfelter \& Storchmann, 2010b; Malheiro et al., 2012; Mozell \& Thach, 2014). Wine is part of the food and beverages market, with multiple sales channels as well as the strong relative market power of the distribution side (Benson-Rea et al., 2003; Hanf et al., 2009; Haucap et al., 2013; Somogyi, 2013). Given the products' high emotional utility, wine also shows characteristics of luxury products (Beverland, 2004, 2005; Hatak, 2008; Higgins \& Wolf, 2016; Hojman, 2015; Kim et al., 2016; Rodrigues \& Rodrigues, 2019; Thode \& Maskulka, 1996). As a result, the characteristics of asset-focused as well as consumer-driven markets with high emotional value and complexity of the product need to be considered in the wine context (Orth et al., 2007). Satisfying the needs of the different worlds, the product complexity as well as the need to deal with the transition of the market as described and the underlying changes of consumers stretches the entrepreneurs and might require technical as well as marketing innovation competence (Dell'Era \& Bellini, 2009; Granata et al., 2019).

Germany is one of the largest wine consumer markets in the world (Anderson \& Nelgen, 2009; OIV, 2011, 2016, 2021). Consumers in Germany annually drink around 2 billion litres of wine, or around 25 litres per capita (BMEL, 2017; DWI, 2020, 2021). Germany in also one of the world's largest wine producers, importing annually almost 15 billion litres of wine (DWI, 2021). International trade and consumer interest in foreign products is a driver for innovation with the import of global new products and practices (Schipperges, 2013; Storchmann, 2018; Trick, 2009). The German wine market is characterised by strong competition on the supplier and declining brand loyalty on the demand side. Suppliers use innovation and strategic shifts (e.g. multi-channel sales or wine \& tourism) to win new clients (Dressler, 2017b). Innovation touches the different areas or functional activities of wineries, encompassing technological innovations, service innovations, and business model innovations (Rantala et al., 2018).

As German wineries are highly integrated, the innovation portfolio potentially affects all steps in the value chain, from harvesting to sales and marketing (Dressler, 2013). Despite a widely acknowledged need to leverage innovation in strategic positioning, restructuring, and change management, there is a reluctance for business model innovation (Dressler, 2020; Pang et al., 2019). Historically, different kinds of innovation have shaped German viticulture, but the most important one has been the mechanisation of viticulture processes (e.g. harvester; overline tractor, trellis education), which has reduced the working hours needed per hectare by $90 \%$, increasing productivity substantially (Oberhofer, 2012). Identifying new potential fields of innovation is important for the modern German wine industry, for wine suppliers, and also for the wider territorial development through co-innovation with other actors.
Given German wineries' entrepreneurial nature and small size, it is necessary to acknowledge resource limitations (Barney, 2001). In the wine industry, tangible and intangible assets such as vineyard and terroir are of paramount importance (Bogonos et al., 2016; Deconinck \& Swinnen, 2013; Van Leeuwen \& Seguin, 2006). Wine is a natural product that is highly impacted by the soil and the location of the vineyard (Ashenfleter \& Storchmann, 2001). Extreme temperature, hail, or other weather have a strong impact on the product and the harvest (Ashenfelter \& Storchmann, 2010a, 2010b).

Securing attractive vineyards is therefore a financial and also a managerial challenge. In densely populated Germany an increasing land grapping of different crops, ecologicalfriendly agriculture (requiring more surface for farming), transportation or energy production, prices for land are on the rise (Bunkus \& Theesfeld, 2018; Herre, 2013; Steinhäußer et al., 2015). Prime vineyards are rarely on the market since they are inherited over generations (Braatz et al., 2007; Rainer et al., 2019; Widder, 2016). Furthermore, the planting of vines is regulated and restricted resulting in increased scarcity of the resource (Bogonos et al., 2016; Deconinck \& Swinnen, 2014; Meloni \& Swinnen, 2016). Limited and costly access to vineyards hence present a financial strain and limitation. Implementing innovation often requires investments (e.g. new and more efficient bottling line). A broad innovation portfolio and simultaneous innovation in all value-chain steps increases the drain (e.g. terroir wines require the best and most costly soil and vineyard (plant); reinvest for fuel-efficient tractors (grow); steep-hill harvester (harvest); heat-regulated barrel fermentation (produce); Customer Relationship Management (CRM) or vineyard management software (organize); newly built wine cellars or fashionable sales rooms to gain attention (sales); access to sales representatives for export markets to profit from growth opportunities (sales). Wineries hence entrepreneurially try to gain and defend positioning and profiling based on resource access (Conner, 1991; Galati et al., 2014; García-Cortijo et al., 2021; Newton et al., 2015).

Resource dependency should accordingly guide strategic innovation management (Begalli et al., 2009; Touzard, 2010). Resource dependency theory fits situations where human and social capital are part of the coordinated resources to realize innovation (Jenssen \& Jorgensen, 2004), as is the case in the German wine industry (Giacomarra et al., 2019). From a practical point of view, awareness of resource limitations and dependency should serve to avoid "bandwaggoning" innovations, where the impetus is not solution driven but an anxiety to miss on opportunities (Abrahamson, 1996, 2000). Indeed, entrepreneurs need to steer their innovation efforts based on strategic fit, effectiveness in regards to operational results, and competitive leverage. In order to do so, there is an urgent need to better understand wineries' portfolio of innovations, that is, the level of innovativeness, but also the value of the different innovations; hence, value measurement becomes key (Moore \& Benbasat, 1991). 


\section{RESEARCH QUESTIONS AND DESIGN}

In order to provide sorely needed insights about the innovation management in small wineries, a multi-case study assessed the innovation activities of four German wineries. The research intended to explore the following questions: What is the individual perception of innovation in the wine industry (case-specific definition)? How are innovations viewed across wineries and what is the common understanding of innovativeness (innovation landscape)? What are the characteristics of the innovation portfolios of individual wineries (innovation profiles)? Does capacity or resource constraints limit the innovation portfolio and therefore require a decision to either focus on front- or back-end innovation (capacity-driven focus)?

The analysis assessed innovation across all steps of the value-creation in wine, from planting (back-end) to production to marketing (front-end). Front-end value creation was determined by possible direct interaction with the clients including the downstream value-creation steps of marketing, delivering and after-sales customer service. Upstream (back-end) value-creation steps were defined by closeness to viti- and viniculture and subsumed planting, growing, harvesting, producing and organizing. This approach served to split the innovation portfolio in viticultural- (back-end) or customer-centric (front-end) innovation areas.

Case research methodology collects in-depth information since few objects are assessed in detail and through a combination data from interviews, visits, and secondary sources (Eisenhardt, 1989; Gilmore \& Carson, 2000; Hill \& Wright, 2001; Simba \& Ojong, 2017; Yin, 2008). The stepwise case analysis approach initially consisted of a discussion of each winery's innovative activities. Then, the innovativeness of the mentioned activities was discussed. Subsequently, the interviewees were asked to state other innovations in the industry. The first examination was realized in each winery in the course of November 2019 until January 2020. In April 2020, winery CEO's were invited to a group discussion on innovation in German wineries. The goal at this stage was to draw a jointly supported map of innovation in the German wine industry at each step of the value-chain and prioritizing the degree to which the innovation is exploratory. Such an approach to innovativeness reflects the status of diffusion: innovation with low exploratory degree shows high adoption of peers' practices and is thereby rated to be less innovative whereas high exploratory innovation means lower diffusion of innovations in the industry. This innovation landscape was then challenged by experts of different wine research institutions in summer 2020. After the 2020 harvest ended, all CEOs were visited again to discuss whether they agree with the innovation landscape and the identified innovation portfolio.

Access to four German wineries allowed for multiple extensive interviews with the wineries' CEOs. The interviews were complemented by several visits to all the wineries. Open interviews on innovation in the wine industry and each winery were complemented with assessing descriptive information (basic company data like size and ownership), strategic orientation (e.g. philosophy) and innovation perception. The data was validated using secondary data from external sources (i.e. statistical data, information in wine guides).

The first winery consisted of a cooperatively organized winery (C1 coop) in the Württemberg region. It represented the largest winery in the sample and its business model represents a cooperative with almost 100 producing vintners and joint annual production of about nine million litres of wine. Case 2 is based on a small, entrepreneurial (SE) winery in the Rheingau wine region under the control and management of the fifth family generation (C2 SMALL). This entrepreneurial winery grew from a mere 4 hectares to more than 10 hectares in the last 15 years. Case 3 is focused on a state-owned winery, which predominantly serves as a research facility but also needs to sell wine produced from more than 20 hectares directly to consumers (C3 STATE). Case 4 is a premium wine estate in southern Palatinate, celebrating its centenary birthday (C4 PREM). The winery produces using a low-yield strategy on about 20 hectares of family-owned vineyards.

The wineries in each case differ in size, ownership structure, and philosophy. Case 2 SMALL represents a "one-man show" with just one employee and production volume of about 100,000 bottles. Case 4 PREM employs seven employees and produces slightly more wine (about 110,000 bottles). Case 3 STATE employs more than 10 employees and produces around 150,000 bottles and case 4 COOP represents a medium-sized company with more than 70 employees and about 10 million wine bottles produced annually (0.75 liters/bottle).

Exploiting CEOs' views on innovations and winery visits to validate the interview information are the core of the analysis. Benchmarking is done on the basis of an innovation grid mapping the most important innovations in the wine industry in the previous decades structured on eight innovation categories based on the value-chain steps of wineries with approximately 80 separate innovation activities. This approach allows for patterns of innovation to emerge from the data, and these patterns, when compared to the four companies' basic data and the views of their CEOs on innovation, yield a picture of innovation in the four selected German wineries.

For each case study, at least two meetings with the CEOs and winery visits served to retrieve the data. The interviews were written down and then transcribed by MaxQDA. Excel served for descriptive statistics. In light of a limited sample and the explorative nature of the study, the emphasis of this study was on the descriptive analysis of wineries' innovative activities.

\section{RESULTS}

The assessment of innovation activities of the cases resulted in a list of unstructured innovation activities which are listed on Table 2.

Innovation in German wineries is about introducing new things, but also about being creative and ahead of one's time. Innovation is a wide-ranging topic, and the analysed wineries accentuated a different range of priorities regarding innovation. Nevertheless, a word occurrence analysis for "top mentioned innovations" across the case studies indicates some commonalities: "labels" were mentioned nine 
Table 1. Overview of Case Studies

\begin{tabular}{|r|c|c|c|c|}
\hline & CASE 1: COOP & CASE 2: SMALL & CASE 3: STATE & CASE 4: PREM \\
\hline Philosophy & $\begin{array}{c}\text { Professional and } \\
\text { customer-centric wine } \\
\text { cooperative }\end{array}$ & $\begin{array}{c}\text { Provision of } \\
\text { enjoyment, } \\
\text { emotion, passion }\end{array}$ & $\begin{array}{c}\text { Creating winning wines } \\
\text { and a turf for research } \\
\text { and training }\end{array}$ & $\begin{array}{c}\text { Outstanding, individual wines } \\
\text { on organic viticulture, quality, } \\
\text { terroir }\end{array}$ \\
\hline Employees & 72 & 1 & 11 & 7 \\
\hline $\begin{array}{r}\text { Size } \\
\text { (approx.) }\end{array}$ & $866 \mathrm{ha}$ & $14 \mathrm{ha}$ & $22 \mathrm{ha}$ ha \\
\hline $\begin{array}{r}\text { Production } \\
\text { (bottles) }\end{array}$ & 9 to $12 \mathrm{million}$ & 105,000 & 150,000 & 110,000 \\
\hline Yield & $85 \mathrm{hl} / \mathrm{ha}$ & $65 \mathrm{hl} / \mathrm{ha}$ & $70 \mathrm{hl} / \mathrm{ha}$ & $55 \mathrm{hl} / \mathrm{ha}$ \\
\hline
\end{tabular}

Table 2. Innovations Mentioned by German Wineries

\begin{tabular}{|c|c|}
\hline \multicolumn{2}{|r|}{ Innovations by Each Winery } \\
\hline $\begin{array}{c}\text { C1 } \\
\text { COOP }\end{array}$ & $\begin{array}{l}\text { - High-end screw caps } \\
\text { - Bordeaux bottles } \\
\text { - Two-part / three-part labels } \\
\text { - Modern labelling } \\
\text { - Switching from mash heating to mash fermentation } \\
\text { - Fermenting a large share of wines in oak barrels } \\
\text { - Developing cuvées specifically targeted at a younger population from production process to branding } \\
\text { - Use of Customer Relationship Management (CRM) software }\end{array}$ \\
\hline $\begin{array}{c}\text { C2 } \\
\text { SMALL }\end{array}$ & $\begin{array}{l}\text { - New visual appearance / corporate design } \\
\text { - Continuing differentiation strategy with the help of CRM software that has an integrated balanced scorecard and } \\
\text { deals with both qualitative and quantitative data on customers }\end{array}$ \\
\hline $\begin{array}{c}\text { C3 } \\
\text { STATE }\end{array}$ & $\begin{array}{l}\text { - Spontaneous fermentation of cuvées in oak barrels } \\
\text { - Fermenting Sauvignon Blanc and new red wine varieties in oak barrels } \\
\text { - Vegan wine production } \\
\text { - Micro oxidation of Pinot Noir for a rounder wine taste } \\
\text { - Mash fermentation } \\
\text { - Separation of cuvées by varieties } \\
\text { - Self-positioning as an innovative, research-oriented wine estate } \\
\text { - New CRM software }\end{array}$ \\
\hline $\begin{array}{c}\text { C4 } \\
\text { PREM }\end{array}$ & $\begin{array}{l}\text { - Establishment of company successors, new generations introducing innovations } \\
\text { - Employing young people from the same age cohort as sommeliers and customers } \\
\text { - IT } \\
\text { - Labels } \\
\text { - New wines classification } \\
\text { - Warehouse expansion } \\
\text { - Price list innovations }\end{array}$ \\
\hline
\end{tabular}

times, “oak barrels" seven times, "fermentation" and "screw caps" six times each, and "harvesting" and "bottling” four times each. Wine packaging-related innovations ("labels", "screw caps", "bottles") and wine production-related innovations ("oak barrel", "fermentation", "harvesting") are on the mind of German wine producers. The domination of product-related innovation illustrates a lag of a proclaimed industry transition to customer centricity (SánchezHernández et al., 2010) whereas indications for productcentrism is repeatedly identified (Dressler, 2013, 2017a; Wilson, 2008; Wilson \& Lockshin, 2003). The word count speaks for a domination of customer-centric innovation focus across the searched wineries. The iterative structuring of winery-specific and general innovation activities alongside the defined value-creation steps resulted in a map shown on Table 3 that was later used to assess each winery's innovation portfolio and compare it with the other cases.

The CEOs jointly agree that cold fermentation belongs to the important innovations in the German wine industry. Other important innovations concern safety, cleanliness, and sustainability: reaching new standards in wine cellar design and processes (e.g. management of oxygen, gentler grape-harvesting machinery with destemming, reinforced stainless steel equipment, implementation of a holistic, low-consumption and eco-friendly energy concept).

Innovation activity and eventual focus of the wineries was assessed calculating the wineries' innovations over all the mentioned innovation activities. Table 4 shows that no winery stated to have implemented all innovation actions that the group identified. The CEOs mentioned innovations with low or no diffusion. C1 COOP though marked highest innovation activity in every value-chain activity. The strong resource base and availability of resources for new investments give it a competitive advantage compared to smaller wineries. In light of the size of this winery, compared to the benchmarking partners, the business model speaks for a lower resource dependency. Indeed, the cooperative business model has size advantage, economies of scale effects, and economies of scope since the organization can draw on different capabilities (Biao, 2017; Lee \& Mulford, 1990; 
Table 3. German Wine Industry Innovation Landscape

\begin{tabular}{|c|c|c|c|c|}
\hline $\begin{array}{l}\text { Explorative } \\
\text { degree }\end{array}$ & (1) PLANT & (2) GROW & (3) HARVEST & (4) PRODUCE \\
\hline \multirow{3}{*}{ top } & Minimal pruning & Wine scout & Optical sorting machine & Blue wine \\
\hline & Own seedlings & $\begin{array}{l}\text { Caterpillar for } \\
\text { steep sides }\end{array}$ & $\begin{array}{l}\text { Harvesting machine with } \\
\text { destemmer }\end{array}$ & iFerm App \\
\hline & & $\begin{array}{l}\text { Overlapping } \\
\text { caterpillar }\end{array}$ & $\begin{array}{l}\text { Harvesting machine for } \\
\text { steep sides }\end{array}$ & $\begin{array}{l}\text { Integrated pump-over } \\
\text { machines }\end{array}$ \\
\hline \multirow{6}{*}{ high } & $\begin{array}{l}\text { Mushroom-resistant } \\
\text { varieties }\end{array}$ & $\begin{array}{l}\text { Tunnelling } \\
\text { trailer with } \\
\text { sprayer }\end{array}$ & Swing destemmer & Wine scan, Grape scan \\
\hline & $\begin{array}{l}\text { Irrigation with } \\
\text { integrated fertiliser }\end{array}$ & $\begin{array}{l}\text { Vine wood } \\
\text { extractor }\end{array}$ & Night harvest & RFID based density test \\
\hline & & & & Barrique management \\
\hline & $\begin{array}{l}\text { New varieties/Cloned } \\
\text { varieties }\end{array}$ & Airfan & $\begin{array}{l}\text { Modern press (with press } \\
\text { program choice) }\end{array}$ & $\begin{array}{l}\text { Fermentation assistant } \\
\text { (software) }\end{array}$ \\
\hline & & & & Staves \\
\hline & & & & Cross-flow filtration \\
\hline & GPS planting & Defoliator & Destemmer & Overpressure tank \\
\hline & & Master brush & Preharvesting/Sorting belt & Mixing tank \\
\hline & & Pre-cutter & & Plunger tank \\
\hline & & Disk stapler & & \\
\hline & Trellis education & $\begin{array}{l}\text { Antidrift } \\
\text { injectors }\end{array}$ & $\begin{array}{l}\text { Gentle grape transport } \\
\text { discharge with vibration }\end{array}$ & Tannin inject \\
\hline & Irrigation & Greening & & Enzyme \\
\hline & & & & Cold maceration \\
\hline & Extended row width & Leaf-cutter & Harvester & Barrels with cooling \\
\hline & & & Dry ice & Cooling systems \\
\hline & & & Sort \& select grapes & \\
\hline \multirow[t]{2}{*}{ standard } & Trellis education & $\begin{array}{l}\text { Rotating } \\
\text { harrow }\end{array}$ & Soft press activities & $\begin{array}{l}\text { White wine in wooden } \\
\text { barrels }\end{array}$ \\
\hline & Extended rows length & & & \\
\hline & Big headland & Hollow cone & & Pump-over chips \\
\hline & Compact clones & & & Wooden barrels \\
\hline low & & Mulcher & & Hand mashing \\
\hline $\begin{array}{l}\text { Explorative } \\
\text { degree }\end{array}$ & (5) ORGANIZE & (6) MARKET & (7) DELIVER & (8) CARE \\
\hline \multirow{3}{*}{ top } & Prosuming & WEB 2.0 (Blog) & $\begin{array}{l}\text { Portioned wine (glass/ } \\
\text { small bottle) }\end{array}$ & Product reviews \\
\hline & Crowdfunding & Twitter & Outsourcing & \\
\hline & Patent/Licensing & Instagram & Integrated RFID & Treasure vault/Wine bank \\
\hline \multirow{3}{*}{ high } & Outsourcing & Restaurant & Light glass bottle & Wine Club \\
\hline & & Bar & Green wine box & CRM exploitation \\
\hline & & Facebook & VinoLok & \\
\hline & Partnerships & Online shop & Bag-in-box & Web pictures, videos \\
\hline & $\begin{array}{l}\text { Sustainable company } \\
\text { management }\end{array}$ & Winery events & Twister & Wine route \\
\hline & Solar cells & $\begin{array}{l}\text { Modern } \\
\text { architecture }\end{array}$ & Label/sleeves remover & Trial packages \\
\hline & Photovoltaic & $\begin{array}{l}\text { Joint venture } \\
\text { marketing }\end{array}$ & Reusable bottles system & $\begin{array}{l}\text { Sponsoring barrel } \\
\text { production }\end{array}$ \\
\hline & Modern wine club & & Delivery tracking system & Sponsoring vine stock \\
\hline
\end{tabular}




\begin{tabular}{|l|l|l|l|l|}
\hline & & Vegan label & & \\
\hline \multirow{5}{*}{ standard } & Efficient use of water & $\begin{array}{l}\text { Innovative } \\
\text { events }\end{array}$ & Screw cap & QR Code \\
\cline { 2 - 5 } & & & Certification & \\
\cline { 2 - 5 } & $\begin{array}{l}\text { Management software } \\
\text { (weinbauonline.de) }\end{array}$ & $\begin{array}{l}\text { Modern } \\
\text { website }\end{array}$ & & $\begin{array}{l}\text { Customer care (Newsletter, } \\
\text { customer letter-emails) }\end{array}$ \\
\cline { 2 - 5 } & & Vinothek & & \\
\hline & Biodynamic cultivation & Awards & Modern glass bottle & Customer cards \\
\hline & Organic cultivation & Sales events & & Prize competition \\
\hline & Cellar underground & Website & & \\
\hline $\begin{array}{l}\text { less } \\
\text { innovative }\end{array}$ & & $\begin{array}{l}\text { Wine tasting } \\
\text { facility }\end{array}$ & Cork cap & \\
\hline
\end{tabular}

Table 4. Innovation Assessment

\begin{tabular}{|c|c|c|c|c|c|c|c|c|}
\hline \multicolumn{9}{|c|}{ Innovation Achievement } \\
\hline & 1 Plant & 2 Grow & 3 Harvest & 4 Produce & 5 Organize & 6 Market & 7 Deliver & 8 Care \\
\hline $\mathrm{CICOOP}$ & $92 \%$ & $94 \%$ & $67 \%$ & $80 \%$ & $92 \%$ & $76 \%$ & $47 \%$ & $57 \%$ \\
\hline C2 SMALL & $42 \%$ & $47 \%$ & $67 \%$ & $45 \%$ & $69 \%$ & $53 \%$ & $35 \%$ & $50 \%$ \\
\hline C3 STATE & $83 \%$ & $59 \%$ & $50 \%$ & $45 \%$ & $31 \%$ & $41 \%$ & $41 \%$ & $43 \%$ \\
\hline C4 PREM & $75 \%$ & $59 \%$ & $58 \%$ & $55 \%$ & $77 \%$ & $71 \%$ & $24 \%$ & $50 \%$ \\
\hline \multicolumn{9}{|c|}{ Innovation Benchmark } \\
\hline Max & $92 \%$ & $94 \%$ & $67 \%$ & $80 \%$ & $92 \%$ & $76 \%$ & $47 \%$ & $57 \%$ \\
\hline $\mathrm{ClCOOP}$ & $100 \%$ & $100 \%$ & $100 \%$ & $100 \%$ & $100 \%$ & $100 \%$ & $100 \%$ & $100 \%$ \\
\hline C2 SMALL & $45 \%$ & $50 \%$ & $100 \%$ & $56 \%$ & $75 \%$ & $69 \%$ & $75 \%$ & $88 \%$ \\
\hline C3 STATE & $91 \%$ & $63 \%$ & $75 \%$ & $56 \%$ & $33 \%$ & $54 \%$ & $88 \%$ & $75 \%$ \\
\hline C4 PREM & $82 \%$ & $63 \%$ & $88 \%$ & $69 \%$ & $83 \%$ & $92 \%$ & $50 \%$ & $88 \%$ \\
\hline
\end{tabular}

Palmer, 2002; Zuckerman \& D’Aunno, 1990). The principles of cooperation and joint decision making has a positive effect on the innovation portfolio, front- and back-end (Biao, 2017; Chang et al., 2012; Giacomarra et al., 2019).

A calculation with $\mathrm{C} 1 \mathrm{COOP}$ as the benchmark (C1 COOP score set as maximum score), served to highlight followers and eventual laggards in the different value chain activities. As shown on Table 4, C3 STATE clearly undervalues organizational innovation. The interviews and secondary analysis revealed that the state-owned winery's investment decisions were more easily approved when asking for technological investments. Organizational improvement or innovation to allow for more attractive marketing is much more difficult to get approval for. As a result of a higher degree of bureaucratisation and foremost dependency on the owning party and the limited access to resources, this winery scored significantly lower in the marketing innovation category, where it has experienced problems running Blogs, using Twitter or Instagram, and expanding into tourism, restaurants and bars, paid wine tastings, and organised events.

C2 SMALL meets the benchmark for harvest innovation activities. Indeed, the winery owner self-identified as a technophile. Furthermore, a lack of employees and support- ive help steer his innovation activities towards securing the most efficient harvest processes (Berends et al., 2014; Servantie \& Rispal, 2018). A strong innovative focus on delivery also finds explanation in a personal preference of these processes by the winery owner. He has been awarded for the creation of a customer relationship management (CRM) tool, surely motivated by his prior career as a management consultant and the fact that he strongly emphasizes after-purchase customer-care activities - again, securing efficiency. Case 2 showed some deficiencies regarding awards, or certifications. The entrepreneurial attitude resulted in limited boundary spanning which is unfortunate since it could have served to lower resource dependency and help the firm excel beyond the scope of the technophile owner's plans.

The premium winery, C4 PREM, puts an emphasis on organizational innovation. Organizing is a means to ensure highly professional processes. Relying strongly on tradition but with a high degree of organization characterize the innovation path that fits C4 PREM's business model. Less emphasis on innovation for the value-chain stage of "delivery" finds explanation as this winery business model strongly profits of direct-to-consumer sales and a loyal customer base. Part of the winery's value proposition is being "high 
Table 5. Innovation Focus

\begin{tabular}{|l|c|c|}
\hline & Back-End & Front-End \\
\hline C1 COOP & $100 \%$ & $100 \%$ \\
\hline C2 SMALL & $65 \%$ & $77 \%$ \\
\hline C3 STATE & $64 \%$ & $72 \%$ \\
\hline C4 PREM & $77 \%$ & $77 \%$ \\
\hline
\end{tabular}

touch", meaning customers can interact with the owners and winery representatives. The winery owner of C4 PREM is network oriented and integrated with a strong emphasis on market activities and customer care, as reflected in the innovation portfolio (Korsgaard et al., 2015; Pang et al., 2019).

A calculated performance index for back-end (plant, grow, harvest, produce, organize) and front-end (market, deliver, care) innovations illustrates that $\mathrm{C} 1 \mathrm{COOP}$ serves as benchmark and also emphasize the need for all players to actively innovate at both the front- and the back-end.

The findings suggests that cooperatives can pave the ground for innovation in the German wine industry. Cooperatives and large companies have a competitive advantage when it comes to innovation because of their ability to systematically invest in strategic innovations. Smaller wineries engage much more in strategic market positioning through focused innovation that allows them to optimally serve clearly delineated market niches. To fully realise the competitive advantages from innovation, the wine industry as a whole needs to adopt an innovation approach that is based on business ecosystems. Still, all market protagonists that aim to cover the whole value-chain inevitably over stretch their innovation portfolio.

\section{IMPLICATIONS, LIMITATIONS AND FUTURE RESEARCH}

The need for practitioners to address and synchronize front- and back-end innovation can be best addressed by industry executives through fitting the innovation strategy to their firm's business model and by overcoming resource dependency through cooperation and exchange. Entrepreneurial innovation management and knowledge exchange help wineries prevent bandwaggoning innovation from innovation diffusion.

This study suffers several limitations. An analysis of four cases cannot be representative of the entire German wine industry and therefore this study only has explorative value. Benchmarking wineries' innovation activities is influenced by subjective perceptions of innovativeness. Technological advances shorten the life-cycle of innovative measures. An measure of innovative performance can quickly become an industry standard. Benchmarking therefore requires permanent update with technological advances. The chosen cases represent a diverse range of business models and therefore the presented results have a bias of differing innovation profiles. Furthermore, country effects need to be acknowledged. The results suggest the need for future research to (a) improve upon the used innovation grid in the light of future technological developments, (b) adapt the grid for country-specific factors, (c) simulate results using different innovation coefficients, and (d) enrich the analyses through additional case analyses.

\section{CONCLUSION}

Innovation is deemed to be a key success factor for wineries operating in increasingly competitive markets. Demands for executives to successfully management their firm's innovation processes is high, considering increasing complexity, financial burdens, shorter product life cycles, and digitalization in the wine industry. Executives of smalland medium-sized enterprises with limited resources face a particularly strong need to wisely manage innovation in their firms. In order to provide an assessment of innovation management in SME wineries, a multi-case study was conducted. The case analysis reveals that resource dependency can best be overcome when profiting from firm size effects and access to cooperative resources. The innovation activities of four German wineries at each step of the value chain was subject to analysis. The observed innovation strategies are in turn explained by the business models and entrepreneurial characteristics of the wineries studied. A closer fit between a winery's business model and its innovation strategy as well as industry-level joint activities can serve to increase wineries' overall innovativeness.

The four cases analysed demonstrate that a) innovation matters, b) strategic positioning influences the innovation portfolio, c) size and organization impact the innovation portfolio, d) resource dependency offers explanation and thereby cooperative action allow to overcome barriers and e) smaller producers must play on their entrepreneurial personality. All integrated wine producers need to address front- and back-end innovation, but carefully observing their winery's innovation accentuation and individual innovation portfolios. The wineries also need to recognize the synergetic value of the two different focal points: convincing products require optimal planting and farming whereas the product assortment and its treatment should consider customer profiles. Hence, front- and back-end innovations need to be synchronized and considered in parallel, without ignoring the individualization of the firm's innovation portfolio. A synergetic innovation approach, exploiting technology and data mining, can foster the development of wineries' competencies through the use of existing wine industry resources and capabilities. Knowledge exchange helps producers reach consensus on innovation activities, goals, and strategies, and to improve the business ecosystem by identifying elements that are obsolete or ripe for change. Diffusion of innovation will be secured when those conditions are met. 
Submitted: July 22, 2021 PDT, Accepted: December 20, 2021

PDT

This is an open-access article distributed under the terms of the Creative Commons Attribution 4.0 International License (CCBY-4.0). View this license's legal deed at http://creativecommons.org/licenses/by/4.0 and legal code at http://creativecommons.org/licenses/by/4.0/legalcode for more information. 


\section{References}

Abrahamson, E. (1991). Managerial fads and fashions: The diffusion and rejection of innovations. Academy of Management Review, 16(3), 586. https://doi.org/10.2 $\underline{307 / 258919}$

Abrahamson, E. (1996). Management Fashion. Academy of Management Review, 21(1), 254-285. https://doi.or $\mathrm{g} / 10.2307 / 258636$

Abrahamson, E. (2000). Change without pain. Harvard Business Review, 78(4), 75-79.

Adner, R., \& Kapoor, R. (2010). Value creation in innovation ecosystems: How the structure of technological interdependence affects firm performance in new technology generations. Strategic Management Journal, 31(3), 306-333. https://doi.org/1 0.1002/smj.821

Agostini, L., \& Filippini, R. (2019). Organizational and managerial challenges in the path toward Industry 4.0. European Journal of Innovation Management, 22(3), 406-421. https://doi.org/10.1108/ejim-02-201 $\underline{8-0030}$

Al-Aali, A. Y., \& Teece, D. J. (2013). Towards the (Strategic) Management of Intellectual Property: Retrospective and Prospective. California Management Review, 55(4), 15-30. https://doi.org/10.1525/cmr.201 $\underline{3.55 .4 .15}$

Anderson, K., \& Nelgen, S. (2009). Global wine markets, 1961 to 2009: A statistical compendium. University of Adelaide Press. https://doi.org/10.1017/upo97809870 $\underline{73013}$

Anonymous. (2018). Das größte Weingut Deutschlands [Focus online].

Ashenfelter, O., \& Storchmann, K. (2010a). Using hedonic models of solar radiation and weather to assess the economic effect of climate change: The case of Mosel Valley vineyards. In World Scientific Reference on Handbook of the Economics of Wine: Volume 1: Prices, Finance, and Expert Opinion (pp. 59-96). World Scientific. https://doi.org/10.1142/9789 $\underline{8132327470003}$

Ashenfelter, O., \& Storchmann, K. (2010b). Measuring the economic effect of global warming on viticulture using auction, retail, and wholesale prices. Review of Industrial Organization, 37(1), 51-64. https://doi.org/ 10.1007/s11151-010-9256-6

Ashenfleter, O., \& Storchmann, K. (2001). The quality of vineyard sites in the Mosel valley of Germany. Napa Valley Conference of the VDQS Society.

Ashton, R. H. (2011). Improving Experts' Wine Quality Judgments: Two Heads Are Better than One. Journal of Wine Economics, 6(2), 160-178. https://doi.org/10.1 $\underline{017 / s 1931436100001577}$

Aylward, D. (2006). Innovation lock-in: Unlocking research and development path dependency in the Australian wine industry. Strategic Change, 15(7-8), 361-372. https://doi.org/10.1002/jsc.768
Aylward, D., Glynn, J., \& Gibson, B. (2006). SME Innovation within the Australian Wine Industry: A Cluster Analysis. Small Enterprise Research, 14(1), 42-54. https://doi.org/10.5172/ser.14.1.42

Barney, J. (2001). Is the Resource-Based View a Useful Perspektive for Strategic Management? Yes. Academy of Management Review, 26(1), 41-56.

Begalli, D., Codurri, S., \& Gaeta, D. (2009). Wine and web marketing strategies: The case study of Italian speciality wineries. British Food Journal, 111(6), 598-619. https://doi.org/10.1108/0007070091096604 1

Benson-Rea, M., Brodie, R. J., \& Cartwright, W. (2003). Strategic issues facing the New Zealand wine industry in a global environment. The Wine Marketing Colloquium, University of South Australia, Adelaide.

Berends, H., Jelinek, M., Reymen, I., \& Stultiëns, R. (2014). Product Innovation Processes in Small Firms: Combining Entrepreneurial Effectuation and Managerial Causation. Journal of Product Innovation Management, 31(3), 616-635. https://doi.org/10.1111/ ipim. 12117

Best, H. (2010). Environmental concern and the adoption of organic agriculture. Society \& Natural Resources, 23(5), 451-468. https://doi.org/10.1080/08 $\underline{941920802178206}$

Beverland, M. (2004). Uncovering "theories-in-use”: Building luxury wine brands. European Journal of Marketing, 38(3/4), 446-466. https://doi.org/10.1108/ 03090560410518648

Beverland, M. (2005). Crafting Brand Authenticity: The Case of Luxury Wine. Journal of Management Studies, 42(5), 1003-1029. https://doi.org/10.1111/j.1467-648 6.2005.00530.x

Biao, S. (2017). The Effects of Cooperative Ambidexterity Competency on Alliance Innovation Performance: A Resource-dependency Perspective. Management Review, 29(11), 98.

BMEL. (2016). Ertragslage Garten- und Weinbau 2016. Bundesministerium für Ernährung und Landwirtschaft.

BMEL. (2017). Ertragslage Garten- und Weinbau.

BMEL. (2019). Ertragslage Garten -und Weinbau 2019. Bundesministerium für Ernährung und Landwirtschaft.

BMEL. (2021). Ertragslage Garten -und Weinbau 2020. Bundesministerium für Ernährung und Landwirtschaft.

BMELV. (2011). Ertragslage Garten -und Weinbau 2011. Bundesministerium für Ernährung, Landwirtschaft und Verbraucherschutz .

BMELV. (2012). Ertragslage Garten -und Weinbau 2012. Bundesministerium für Ernährung, Landwirtschaft und Verbraucherschutz. 
Bogonos, M., Engler, B., Oberhofer, J., Dressler, M., \& Dabbert, S. (2016). Planting Rights Liberalization in the European Union: An Analysis of the Possible Effects on the Wine Sector in Rheinland-Pfalz, Germany. German Journal of Agricultural Economics, 65(1), 30-40.

Braatz, D., Sautter, U., \& Swoboda, I. (2007). Weinatlas Deutschland. Gräfe und Unzer.

Bunkus, R., \& Theesfeld, I. (2018). Land grabbing in Europe? Socio-cultural externalities of large-scale land acquisitions in East Germany. Land, 7(3), 98. htt ps://doi.org/10.3390/land7030098

Calantone, R. J., Cavusgil, S. T., \& Zhao, Y. (2002). Learning orientation, firm innovation capability, and firm performance. Industrial Marketing Management, 31(6), 515-524. https://doi.org/10.1016/s0019-8501(0 1)00203-6

Calantone, R. J., \& Rubera, G. (2012). When Should RD\&E and Marketing Collaborate? The Moderating Role of Exploration-Exploitation and Environmental Uncertainty. Journal of Product Innovation Management, 29(1), 144-157. https://doi.org/10.1111/ j.1540-5885.2011.00884.x

Camisón, C., \& Monfort-Mir, V. M. (2012). Measuring innovation in tourism from the Schumpeterian and the dynamic-capabilities perspectives. Tourism Management, 33(4), 776-789. https://doi.org/10.1016/ j.tourman.2011.08.012

Caputo, A. C., Cucchiella, F., Fratocchi, L., Pelagagge, P. M., \& Scacchia, F. (2002). A methodological framework for innovation transfer to SMEs. Industrial Management \& Data Systems, 102(5), 271-283. http s://doi.org/10.1108/02635570210428302

Carter, A. P. (1990). Upstream and downstream benefits of innovation. Economic Systems Research, 2(3), 241-257. https://doi.org/10.1080/09535319000000017

Chang, C.-W., Chiang, D. M., \& Pai, F.-Y. (2012). Cooperative strategy in supply chain networks. Industrial Marketing Management, 41(7), 1114-1124. $\underline{\mathrm{h}}$ ttps://doi.org/10.1016/j.indmarman.2012.04.011

Chesbrough, H. (2010). Business model innovation: Opportunities and barriers. Long Range Planning, 43(2-3), 354-363. https://doi.org/10.1016/j.lrp.2009.0 7.010

Cochrane, W. W. (1958). Farm Prices, Myth and Reality. University of Minnesota Press.

Conner, K. R. (1991). A Historical Comparison of Resource-Based Theory and Five Schools of Thought Within Industrial Organization Economics: Do We Have a New Theory of the Firm? Journal of Management, 17(1), 121-154. https://doi.org/10.1177/ 014920639101700109

Corsi, A. M., Lockshin, L., \& Mueller, S. (2011). Competition between and competition within: The strategic positioning of competing countries in key export markets. Paper Presented at the 6th International Conference.

Crossan, M. M., \& Apaydin, M. (2010). A MultiDimensional Framework of Organizational Innovation: A Systematic Review of the Literature. Journal of Management Studies, 47(6), 1154-1191. http s://doi.org/10.1111/j.1467-6486.2009.00880.x
Dana, L. P., \& Dana, T. E. (2005). Expanding the scope of methodologies used in entrepreneurship research. International Journal of Entrepreneurship and Small Business, 2(1), 79. https://doi.org/10.1504/ijesb.200 $\underline{5.006071}$

Danneels, E. (2002). The dynamics of product innovation and firm competences. Strategic Management Journal, 23(12), 1095-1121. https://doi.o $\mathrm{rg} / 10.1002 / \mathrm{smj} .275$

Datamonitor. (2010). Wine Industry Profile: Germany. htt p://search.ebscohost.com/login.aspx?direct=true\&d $\mathrm{b}=$ buh \&AN $=51689551$ \&site $=$ ehost-live

D’Aveni, R. (1994). Hypercompetition: The Dynamics of Strategic Maneuvering. Basic Books.

Deconinck, K., \& Swinnen, J. (2013). The economics of planting rights. AAWE.

Deconinck, K., \& Swinnen, J. (2014). The economics of planting rights in wine production. European Review of Agricultural Economics, 42(3), 419-440. https://do i.org/10.1093/erae/ibu028

Dell'Era, C., \& Bellini, E. (2009). How can product semantics be embedded in product technologies? The case of the Italian wine industry. International Journal of Innovation Management, 13(3), 411-439. https://do i.org/10.1142/s1363919609002364

Denton, D. K. (1999). Gaining competitiveness through innovation. European Journal of Innovation Management, 2(2), 82-85. https://doi.org/10.1108/146 01069910269790

Doepfer, B. C. (2012). Co-innovation competence: $A$ strategic approach to entrepreneurship in regional innovation structures. Katolische Universität EichstättIngolstadt.

Dressler, M. (2013). Innovation management of German wineries: From activity to capacity-an explorative multi-case survey. Wine Economics and Policy, 2(1), 19-26. https://doi.org/10.1016/j.wep.2013.05.002

Dressler, M. (2016). Exploring prosuming interest strategic customer integration. Wine Economics and Policy, 5(1), 24-32. https://doi.org/10.1016/i.wep.201 $\underline{6.04 .002}$

Dressler, M. (2017a). Strategic grouping in a fragmented market: SMEs' strive for legitimacy. International Journal of Entrepreneurship and Small Business, 32(1-2), 229-253. https://doi.org/10.1504/ijesb.201 7.085996

Dressler, M. (2017b). Strategic Profiling and the value of wine \& tourism initiatives: Exploring strategic grouping of German wineries. International Journal of Wine Business Research, 29(4), 484-502. https://doi.or g/10.1108/ijwbr-04-2017-0026

Dressler, M. (2018). The German Wine Market: A Comprehensive Strategic and Economic Analysis. Beverages, 4(4), 92. https://doi.org/10.3390/beverages $\underline{4040092}$

Dressler, M. (2020). The entrepreneurship power house of ambition and innovation: Exploring German wineries. International Journal of Entrepreneurship and Small Business, 41(3), 397-430. https://doi.org/10.150 4/ijesb.2020.110796 
Dressler, M., \& Paunović, I. (2019). Towards a conceptual framework for sustainable business models in the food and beverage industry: The case of German wineries. British Food Journal, 122(5), 1421-1435. https://doi.org/10.1108/bfj-03-2019-0214

Dressler, M., \& Paunović, I. (2020). Converging and diverging business model innovation in regional intersectoral cooperation-exploring wine industry 4.0. European Journal of Innovation Management.

DWI. (2020). Deutscher Wein Statistik 2019/2020.

DWI. (2021). Deutscher Wein Statistik 2020/2021.

Eisenhardt, K. M. (1989). Building Theories from Case Study Research. The Academy of Management Review, 14(4), 532. https://doi.org/10.2307/258557

Fischer, E. (2011). Die Identifikation der kooperativen Kernkompetenzen am Beispiel der "Gesundheits- und Wellness"- Destination Bayern. In H. Pechlaner, E. Fischer, \& M. Bachinger (Eds.), Kooperative Kernkompetenzen Management von Netzwerken in Regionen und Destinationen (pp. 111-142). Gabler Verlag.

Forsman, H. (2011). Innovation capacity and innovation development in small enterprises. A comparison between the manufacturing and service sectors. Research Policy, 40(5), 739-750. https://doi.org/10.10 16/j.respol.2011.02.003

Freel, M. (2005). The characteristics of innovationintensive small firms: Evidence from "Northern Britain.” International Journal of Innovation Management, 9(4), 401-429. https://doi.org/10.1142/s 1363919605001320

Galati, A., Crescimanno, M., Rossi, M., Farruggia, D., \& Tinervia, S. (2014). The determinants affecting the internationalisation of the Italian SMEs producing sparkling wines: An empirical study on the RBV of the firms. International Journal of Globalisation and Small Business, 6(2), 100-118. https://doi.org/10.1504/ijgs $\underline{\text { b.2014.066463 }}$

Garcia, F. A., Marchetta, M. G., Camargo, M., Morel, L., \& Forradellas, R. Q. (2012). A framework for measuring logistics performance in the wine industry. International Journal of Production Economics, 135(1), 284-298. https://doi.org/10.1016/j.ijpe.2011.08.003

Garcia, R., \& Calantone, R. J. (2002). A critical look at technological innovation typology and innovativeness terminology: A literature review. Journal of Product Innovation Management, 19(2), 110-132. https://doi.org/10.1111/1540-5885.1920110

García-Cortijo, M. C., Ferrer, J. R., Castillo-Valero, J. S., \& Pinilla, V. (2021). The Drivers of the Sustainability of Spanish Wineries: Resources and Capabilities. Sustainability, 13(18), 10171. https://doi.org/10.3390/s u131810171

García-Villaverde, P. M., Ruiz-Ortega, M. J., \& Ignacio Canales, J. (2013). Entrepreneurial orientation and the threat of imitation: The influence of upstream and downstream capabilities. European Management Journal, 31(3), 263-277. https://doi.org/10.1016/i.em j.2012.11.006
Giacomarra, M., Shams, S. R., Crescimanno, M., Sakka, G., Gregori, G. L., \& Galati, A. (2019). Internal vs. external R\&D teams: Evidences from the Italian wine industry. Journal of Business Research.

Gilinsky, A., Jordan, D., \& Newton, S. K. (2014). Vive La Difference! An Empirical Investigation into Status, Innovation, and Financial Performance in The Wine Industry. The 8th international conference, Geisenheim.

Gilinsky, A., Jr., Forbes, S. L., \& Reed, M. M. (2016). Writing cases to advance wine business research and pedagogy: A Business Article by. Wine Economics and Policy, 5(1), 60-67. https://doi.org/10.1016/j.wep.201 $\underline{6.04 .001}$

Gilinsky, A., Santini, C., Lazzeretti, L., \& Eyler, R. (2008). Desperately seeking serendipity. International Journal of Wine Business Research, 20(4), 302-320. htt ps://doi.org/10.1108/17511060810919425

Gilmore, A., \& Carson, D. (2000). The demonstration of a methodology for assessing SME decision making. Journal of Research in Marketing and Entrepreneurship, 2(2), 108-124. https://doi.org/10.1108/147152000800 $\underline{01542}$

Giuliani, P., Robert, M., \& Le Roy, F. (2017). Reinvention of management innovation for successful implementation. International Journal of Entrepreneurship and Small Business.

Glynn, M. A. (1996). Innovative genius: A framework for relating individual and organizational intelligences to innovation. Academy of Management Review, 21(4), 1081-1111. https://doi.org/10.5465/amr.1996.970407 $\underline{1864}$

Goldsmith, R. E. (2000). Identifying Wine Innovators: A Test of the Domain Specific Innovativeness Scale Using Known Groups. International Journal of Wine Marketing, 12(2), 37-46. https://doi.org/10.1108/eb00 $\underline{8708}$

Granata, J., Aytaç, B., \& Roubaud, D. (2019). Innovation developments in the wine industry: A journey from the amphorae of old to the California wine cluster. International Journal of Entrepreneurship and Small Business, 36(3), 249-255. https://doi.org/10.1504/ijes b.2019.097742

Hanf, J., Schweickert, E., \& Belaya, V. (2009). Power asymmetries in the wine chain: Implications for the management of the chain. Enometrica, 2(1), 29-46.

Harmsen, H., Grunert, K. G., \& Declerck, F. (2000). Why did we make that cheese? An empirically based framework for understanding what drives innovation activity. R\&D Management, 30(2), 151-166. https://do i.org/10.1111/1467-9310.00165

Harrison, B. (1994). Planning in specific companies and situations - SMEs. Long Range Planning, 27(6), 180. ht tp://search.ebscohost.com/login.aspx?direct=true \&d $\mathrm{b}=$ buh \&AN $=12351494$ \& site $=$ ehost-live

Hatak, I. S. (2008). Purchasing wine as a gift; influencing factors and preferences. 4 th International Conference of the Academy of Wine Business Research, 17-19 July, 2008, Siena.

Haucap, J., Heimeshoff, U., Klein, G. J., Rickert, D., \& Wey, C. (2013). Wettbewerbsprobleme im Lebensmitteleinzelhandel. 
Hauschildt, J. (2004). Innovationsmanagement (3rd ed.). Verlag Vahlen.

Herre, R. (2013). Land concentration, land grabbing and options for change in Germany. Land Concentration, 48.

Higgins, L., \& Wolf, M. M. (2016). Millennials as luxury wine buyers in the United States? International Journal of Wine Business Research, 28(3), 190-205. htt ps://doi.org/10.1108/ijwbr-08-2015-0029

Hill, J., \& Wright, L. T. (2001). A qualitative research agenda for small to medium-sized enterprises. Marketing Intelligence \& Planning, 19(6), 432-443. htt ps://doi.org/10.1108/eum0000000006111

Hoffman, D. (2013). Struktur und Entwicklung des Weinmarktes in Deutschland. In H.-R. Schultz \& M. Stoll (Eds.), Weinbaujahrbuch 2014 (Vol. 65, pp. 242-245). Ulmer.

Hojman, D. E. (2015). Radical innovation in luxury carmenere wine from Chile. Journal of Wine Research, 26(1), 40-63. https://doi.org/10.1080/09571264.201 $\underline{4.992398}$

Jenssen, J. I., \& Jorgensen, G. (2004). How do corporate champions promote innovations? International Journal of Innovation Management, 08(1), 63-86. http s://doi.org/10.1142/s1363919604000964

Johannessen, J., Olaisen, J., Johannessen, J., \& Olsen, B. (1999). Managing and organizing innovation in the knowledge economy. European Journal of Innovation Management, 2(3), 116-128. https://doi.org/10.1108/1 4601069910289059

Jørgensen, F., \& Ulhøi, J. P. (2010). Enhancing Innovation Capacity in SMEs through Early Network Relationships. Creativity and Innovation Management, 19(4), 397-404. https://doi.org/10.1111/j.1467-8691.2 010.00577.x

Kenney, M., Serhan, H., \& Trystram, G. (2020). Digitization and platforms in agriculture: Organizations, power asymmetry, and collective action solutions. Power Asymmetry, and Collective Action Solutions. SSRN Electronic Journal. https://do i.org/10.2139/ssrn.3638547

Khan, S. N., \& Mohsin, M. (2017). The power of emotional value: Exploring the effects of values on green product consumer choice behavior. Journal of Cleaner Production, 150, 65-74. https://doi.org/10.101 6/j.jclepro.2017.02.187

Kim, J.-E., Lloyd, S., \& Cervellon, M.-C. (2016). Narrative-transportation storylines in luxury brand advertising: Motivating consumer engagement. Journal of Business Research, 69(1), 304-313. https://d oi.org/10.1016/j.jbusres.2015.08.002

Kirner, E., Kinkel, S., \& Jaeger, A. (2009). Innovation paths and the innovation performance of lowtechnology firms-An empirical analysis of German industry. Research Policy, 38(3), 447-458. https://do i.org/10.1016/i.respol.2008.10.011

Knight, G. A., \& Cavusgil, S. T. (2004). Innovation, organizational capabilities, and the born-global firm. Journal of International Business Studies, 35(2), 124-141. https://doi.org/10.1057/palgrave.jibs.84000 $\underline{71}$
Korsgaard, S., Ferguson, R., \& Gaddefors, J. (2015). The best of both worlds: How rural entrepreneurs use placial embeddedness and strategic networks to create opportunities. Entrepreneurship \& Regional Development, 27(9-10), 574-598. https://doi.org/10.1 $\underline{080 / 08985626.2015 .1085100}$

Lambeck, M. (2013). Deutschlands größtes Weingut. BildZeitung.

Le Roy, F., Robert, M., \& Giuliani, P. (2018). The concept of management innovation: Definition, state of the art and future research avenues. International Journal of Entrepreneurship and Small Business, 35(1), 44. http s://doi.org/10.1504/ijesb.2018.094277

Lecat, B., Brouard, J., \& Chapuis, C. (2017). Fraud and counterfeit wines in France: An overview and perspectives. British Food Journal, 119(1), 84-104. htt ps://doi.org/10.1108/bfj-09-2016-0398

Lee, M. Y., \& Mulford, C. L. (1990). Reasons Why Japanese Small Businesses Form Cooperatives: An Exploratory Study of Three Successful Cases. Journal of Small Business Management, 28(3), 62.

Loose, S., \& Pabst, E. (2018). Current State of the German and International Wine Markets. Oceania, 67, 92-101.

Lubell, M., Hillis, V., \& Hoffman, M. (2011). Innovation, Cooperation, and the Perceived Benefits and Costs of Sustainable Agriculture Practices. Ecology and Society, 16(4), 1-12. https://doi.org/10.5751/es-04389-160423

Lucke, D. (1995). Akzeptanz: Legitimität in der "Abstimmungsgesellschaft." Leske+Budrich.

Lundvall, B. A. (1992). National Systems of Innovation: Towards a Theory of Innovation and Interactive Learning. Pinter.

Malheiro, A. C., Santos, J. A., Pinto, J. G., \& Jones, G. V. (2012). European Viticulture Geography in a changing climate. OIV Bulletin, 85(971), 15-22.

Marion, T. J., Friar, J. H., \& Simpson, T. W. (2012). New Product Development Practices and Early-Stage Firms: Two In-Depth Case Studies. Journal of Product Innovation Management, 29(4), 639-654. https://doi.o rg/10.1111/j.1540-5885.2012.00930.x

Mazzarol, T., \& Reboud, S. (2008). The role of complementary actors in the development of innovation in small firms. International Journal of Innovation Management, 12(2), 223-253. https://doi.o $\mathrm{rg} / 10.1142 / \mathrm{s} 1363919608001960$

McGee, J. E. S. (2000). Responding to Industry Consolidation in Fragmented Industries: The Role of Capabilities in Small Business Survival. Journal of Small Business Strategy, 11(2), 21-32.

Meloni, G., \& Swinnen, J. (2016). The political and economic history of vineyard planting rights in Europe: From Montesquieu to the European Union. Journal of Wine Economics, 11(3), 379-413. https://do i.org/10.1017/jwe.2016.18

Minnici, M., \& Merlin, B. (2016). Fusionen zwischen Winzer-bzw. Weingärtner-genossenschaften in Deutschland-ein Erfolgsmodell? 
Moore, G. C., \& Benbasat, I. (1991). Development of an instrument to measure the perceptions of adopting an information technology innovation. Information Systems Research, 2(3), 192-222. https://doi.org/10.12 87/isre.2.3.192

Mozell, M. R., \& Thach, L. (2014). The impact of climate change on the global wine industry: Challenges \& solutions. Wine Economics and Policy, 3(2), 81-89. htt ps://doi.org/10.1016/j.wep.2014.08.001

Müller, A. E., \& Bürgelt, D. (2006). Weine aus der Neuen Welt in den Regalen der Alten Welt. In (Vol. 1). I\&I Uni Kiel. https://www.agric-econ.uni.kiel.de

Newton, S. K., Gilinsky, A. J., \& Jordan, D. (2015). Differentiation strategies and winery financial performance: An empirical investigation. Wine Economics and Policy, 4(2), 88-97. https://doi.org/10.1 016/j.wep.2015.10.001

Oberhofer, J. (2011). Agrarbericht 2011: Gewinne regelrecht eingebrochen. Der Deutsche Weinbau, 24, 26-31.

Oberhofer, J. (2012). Entwicklung des Arbeitskraftaufwandes im Weinbau 1880-2010.

OECD. (2004). Promoting Entrepreneurship and Innovation in a Global Economy. Istanbul: 2nd OECD Conference of Ministers Responsible for Small to Medium Sized Enterprises.

OIV. (2011). World Statistics.

OIV. (2016). World Vitiviniculture Situation 2016.

OIV. (2021). State of the vitivinicultural world in 2020 [Press release].

Orth, U. R., Lockshin, L., \& d'Hauteville, F. (2007). The global wine business as a research field. International Journal of Wine Business Research, 19(1), 5-13. http s://doi.org/10.1108/17511060710740316

Palmer, A. (2002). Cooperative marketing associations: An investigation into the causes of effectiveness. Journal of Strategic Marketing, 10(2), 135-156. http s://doi.org/10.1080/09652540210125288

Pang, C., Wang, Q., Li, Y., \& Duan, G. (2019). Integrative capability, business model innovation and performance. European Journal of Innovation Management, 22(3), 541-561. https://doi.org/10.1108/ ejim-09-2018-0208

Porter, M. E. (2000). Location, Competition, and Economic Development: Local Clusters in a Global Economy. Economic Development Quarterly, 14(1), 15-34. https://doi.org/10.1177/089124240001400105

Prajogo, D. I., \& Ahmed, P. K. (2006). Relationships between innovation stimulus, innovation capacity, and innovation performance. $R \& D$ Management, 36(5), 499-515. https://doi.org/10.1111/j.1467-9310.2 006.00450.X

Rainer, G., Kister, J., \& Steiner, C. (2019). Qualifizierungsstrategien in regionalen Restrukturierungsprozessen. geographische zeitschrift, 107(2), 130. https://doi.org/10.25162/gz-2019-0007

Rama, R. T., \& von Tunzelmann, N. (2008). Empirical Studies of Innovation in the Food and Beverage Industry. In R. Rama (Ed.), Handbook of Innovation in the Food and Drink Industry (pp. 13-50). The Haworth Press.
Rantala, T., Ukko, J., Saunila, M., \& Havukainen, J. (2018). The effect of sustainability in the adoption of technological, service, and business model innovations. Journal of Cleaner Production, 172, 46-55. https://doi.org/10.1016/i.jclepro.2017.10.009

Remaud, H., \& Couderc, J.-P. (2006). Wine Business Practices: A New Versus Old Wine World Perspective. Agribusiness, 22(3), 405-416. https://doi.org/10.1002/ agr.20094

Rodrigues, C., \& Rodrigues, P. (2019). Brand love matters to Millennials: The relevance of mystery, sensuality and intimacy to neo-luxury brands. Journal of Product \& Brand Management, 28(7), 830-848. http s://doi.org/10.1108/jpbm-04-2018-1842

Rogers, E. M. (1995). Diffusion of Innovations: Modifications of a model for telecommunications. In Die diffusion von innovationen in der telekommunikation (pp. 25-38). Springer.

Rössel, J. B. (2012). Quality classification in competition: Price formation in the German wine market (AAWE, Working Paper 114.).

Roy, S., \& Sivakumar, K. (2010). Innovation generation in upstream and downstream business relationships. Journal of Business Research, 63(12), 1356-1363. http s://doi.org/10.1016/j.jbusres.2010.08.012

Salavou, H. (2004). The concept of innovativeness: Should we need to focus? European Journal of Innovation Management, 7(1), 33-44. https://doi.org/1 $\underline{0.1108 / 14601060410515628}$

Sánchez-Hernández, J. L., Aparicio-Amador, J., \& Alonso-Santos, J. L. (2010). The shift between worlds of production as an innovative process in the wine industry in Castile and Leon (Spain). Geoforum, 41(3), 469-478. https://doi.org/10.1016/j.geoforum.2009.1 $\underline{2.004}$

Santini, C., Cavicchi, A., Gilinsky, A., Newton, S., \& Rabino, S. (2014). Niche Strategy and Resources: Dilemmas and open questions, an exploratory study. Academy of Wine Business Research, 8th international conference.

Saunila, M. (2020). Innovation capability in SMEs: A systematic review of the literature. Journal of Innovation \& Knowledge, 5(4), 260-265. https://doi.or g/10.1016/j.jik.2019.11.002

Scheuermann, M. (2012). Die 50 größten Weingüter.

Schipperges, M. (2013). Verbraucher offen für neue Entdeckungen. Das Deutsche Weinmagazin, 17(18), 58-63.

Schnabel, H., \& Storchmann, K. (2010). Prices as quality signals: Evidence from the wine market. Journal of Agricultural \& Food Industrial Organization, 8(1). http s://doi.org/10.2202/1542-0485.1283

Schneider, S., \& Spieth, P. (2013). Business model innovation: Towards an integrated future research agenda. International Journal of Innovation Management, 17(01), 1340001. https://doi.org/10.114 2/s136391961340001x

Schrader, C. (2008). Reputation und Kaufverhalten: Eine empirische Analyse am Beispiel der Vermarktung deutscher Weine in Großbritannien. Universität Hamburg. 
Schuhmacher, M. C., Kuester, S., \& Hultink, E. J. (2018). Appetizer or Main Course: Early Market vs. Majority Market Go-to-Market Strategies for Radical Innovations. Journal of Product Innovation Management, 35(1), 106-124. https://doi.org/10.1111/ jpim. 12379

Schumpeter, J. A. (1939). Business Cycles - A Theoretical, Historical, and Statistical Analysis of the Capitalist Process.

Scozzi, B., Garavelli, C., \& Crowston, K. (2005). Methods for modeling and supporting innovation processes in SMEs. European Journal of Innovation Management, 8(1), 120-137. https://doi.org/10.1108/146010605105 $\underline{78619}$

Servantie, V., \& Rispal, M. H. (2018). Bricolage, effectuation, and causation shifts over time in the context of social entrepreneurship. Entrepreneurship \& Regional Development, 30(3-4), 310-335. https://do i.org/10.1080/08985626.2017.1413774

Simba, A., \& Ojong, N. (2017). Engaged scholarship: Encouraging interactionism in entrepreneurship and small-to-medium enterprise (SME) research. Journal of Small Business and Enterprise Development, 24(4), 1009-1027. https://doi.org/10.1108/jsbed-03-2017-01 $\underline{26}$

Singer, M., \& Donoso, P. (2008). Upstream or downstream in the value chain? Journal of Business Research, 61(6), 669-677. https://doi.org/10.1016/j.jb usres.2007.06.043

Somogyi, S. (2013). Grape grower and winery relationships: A segmentation approach. International Journal of Wine Business Research, 25(4), 252-266. htt ps://doi.org/10.1108/ijwbr-03-2012-0010

Statistisches Bundesamt. (2010). Landwirtschaft, Forstwirtschaft, Fischerei- Landwirtschaftliche Bodennutzung-Rebflächen.

Steinhäußer, R., Siebert, R., Steinführer, A., \& Hellmich, M. (2015). National and regional land-use conflicts in Germany from the perspective of stakeholders. Land Use Policy, 49, 183-194. https://do i.org/10.1016/j.landusepol.2015.08.009

Stoeberl, P. A., Parker, G. E., \& Joo, S.-J. (1998). Relationship between organizational change and failure in the wine industry: An event history analysis. Journal of Management Studies, 35(4), 537-555. https://doi.org/10.1111/1467-6486.00108

Storchmann, K. (2012). Wine Economics. Journal of Wine Economics, 7(1), 1-33. https://doi.org/10.1017/jwe.20 $\underline{12.8}$

Storchmann, K. (2018). Germany, Austria and Switzerland. In Wine Globalization: A New Comparative History (p. 92).

Taplin, I. M. (2012). Innovation and market growth in a new 'New World' wine region: The case of North Carolina. Journal of Wine Research, 23(3), 229-246. ht tps://doi.org/10.1080/09571264.2012.690090

Teece, D. J. (2007). Explicating dynamic capabilities: The nature and microfoundations of (sustainable) enterprise performance. Strategic Management Journal, 28(13), 1319-1350. https://doi.org/10.1002/s $\underline{\text { mi. } 640}$
Terziovski, M. (2010). Innovation practice and its performance implications in small and medium enterprises (SMEs) in the manufacturing sector: A resource-based view. Strategic Management Journal, 31(8), 892-902. https://doi.org/10.1002/smj.841

Thode, S. F., \& Maskulka, J. M. (1996). A brand equity strategy for ultra-premium California wines. International Journal of Wine Marketing, 8(3), 5-22. htt ps://doi.org/10.1108/eb008659

Thomas, L. C., Painbéni, S., \& Barton, H. (2013). Entrepreneurial marketing within the French wine industry. International Journal of Entrepreneurial Behavior \& Research, 19(2), 238-260. https://doi.org/1 $\underline{0.1108 / 13552551311310392}$

Touzard, J.-M. (2010). Innovation Systems and Regional Vineyards. The ISDA, Montpellier.

Trick, S. (2009). Der deutsche Wein und die Globalisierung: Vol. Band 31. Europäischer Hochschulverlag.

Van de Ven, A. H. (1986). Central problems in the management of innovation. Management Science, 32(5), 590-607. https://doi.org/10.1287/mnsc.32.5.59 $\underline{0}$

Van Leeuwen, C., \& Seguin, G. (2006). The concept of terroir in viticulture. Journal of Wine Research, 17(1), 1-10. https://doi.org/10.1080/09571260600633135

Verbeke, W. (2005). Agriculture and the food industry in the information age. European Review of Agricultural Economics, 32(3), 347-368. https://doi.org/10.1093/eu rrag/jbi017

Vermeulen, P. A. M., De Jong, J. P. J., \& O’Shaughnessy, K. C. (2005). Identifying key determinants for new product introductions and firm performance in small service firms. Service Industries Journal, 25(5), 625-640. https://doi.org/10.1080/0264206050010078 $\underline{3}$

Vrontis, D., Bresciani, S., \& Giacosa, E. (2016). Tradition and innovation in Italian wine family businesses. British Food Journal, 118(8), 1883-1897. https://doi.or g/10.1108/bfj-05-2016-0192

Wang, C. L., \& Ahmed, P. K. (2004). The development and validation of the organisational innovativeness construct using confirmatory factor analysis. European Journal of Innovation Management, 7(4), 303-313. https://doi.org/10.1108/1460106041056505 6

Widder, C. (2016). Leitfaden zur Verkehrswertermittlung von Heurigenimmobilien und Weingärten.

Wilson, D. (2008). Identifying successful marketing practices for wine packaging innovations. Bulletin de l'OIV-Organisation Internationale de La Vigne et Du Vin, 81(923-925), 113.

Wilson, D., \& Lockshin, L. (2003). The communications issues for producers of alternative closures in the wine industry. University of South Australia.

Wood, S., \& Hoeffler, S. (2013). Looking Innovative: Exploring the Role of Impression Management in High-Tech Product Adoption and Use. Journal of Product Innovation Management, 30(6), 1254-1270. ht tps://doi.org/10.1111/jpim.12134

Woodward, D. (2005). Porter`s Cluster Strategy Versus Industrial Targeting. In Paper presented at the ICIT. 
Yin, R. K. (2008). Case Study Research (4. Auflage). Sage Publications.
Zuckerman, H. S., \& D’Aunno, T. A. (1990). Hospital alliances: Cooperative strategy in a competitive environment. Health Care Management Review, 15(2), 21-30. https://doi.org/10.1097/00004010-19900152 0-00007 